\title{
空間掃引を用いた産業用マニピュレータの教示*
}

\author{
前田雄 介*1, 潮田達也*2

\section{Teaching of Industrial Manipulators by Manual Volume Sweeping}

\author{
Yusuke MAEDA*3 and Tatsuya USHIODA \\ ${ }^{* 3}$ Division of Systems Research, Faculty of Engineering, Yokohama National University, \\ 79-5 Tokiwadai, Hodogaya-ku, Yokohama-shi, Kanagawa, 240-8501 Japan
}

\begin{abstract}
In this paper, we propose a robot teaching method for industrial manipulators. It enables novice human operators to teach "good" robot motions in a short period of time. First in this method, a human operator makes a robot manipulator sweep a volume by its bodies. The manipulator is equipped with a force sensor on its wrist and damping-controlled; the operator can move it freely by grasping its end-effector. The swept volume stands for (a part of) the manipulator's free space, because the manipulator has passed through the volume without collisions. Next, the obtained swept volume is used by a motion planner to generate a well-optimized path of the manipulator automatically. Finally, the planned motion is executed by the manipulator. Even non-skilled operators can generate robot motions with short cycle time by doing the above procedure. The effectiveness of our method was successfully demonstrated in teaching experiments for a comparison with other conventional methods.
\end{abstract}

Key Words : Manipulator, Robot, Planning, Robot Teaching, Swept Volumes, Motion Planning

\section{1. 序論}

現在の産業用ロボットマニピュレータに作業を行わ せるためには教示が必要であり, ティーチングプレイ バックなどの方法でオペレータがロボットの動作を詳 細に教えなければならない.しかし, 教示は非熟練者 には時間のかかる厄介な作業であり，この手間が中小 企業などへのロボットの普及を阻む一つの大きな要因 になっている.このため, 非熟練者にとっても簡単な ロボット教示法の実現が強く望まれている.

これまでにも教示を簡単化するための取り組みはさ まざまに行われている.たとえばオフライン教示 ${ }^{(1)}$ は, 実ロボットを占有せずに安全に教示を行う手法として 普及が進んでいる. また, マニピュレータの動作計画 アルゴリズムは精力的に研究されており ${ }^{(2) ~(5)}$, (準) 最 適なロボットの動作を自動生成することも可能となっ ている.

しかし，オフライン教示には，仮想環境と実環境と の不一致の問題がある. ロボットの設置位置や動作に は必ず誤差が存在するため, 実環境での動作実行時に

* 原稿受付 2007 年 8 月 13 日.

*1 正員, 横浜国立大学大学院工学研究院 (画 240-8501 横浜市保 土ヶ谷区常盤台 79-5).

*2 横浜国立大学大学院工学府.

E-mail : maeda @ynu.ac.jp
はその分の調整が必要となり，これは面倒な作業であ る.さらに, 動作計画アルゴリズムによる動作の自動 生成を行うためには，障害物などの環境情報をシステ ムに取り込む必要があるが, これもかなりの手間を要 する.

オンラインでの教示に関しては, 直感的な教示法と して直接教示 ${ }^{(6)}$ が一部で用いられている. 直接教示 では, ロボットが力制御された状態で, オペレータが エンドェフェクタをつかんで適切な位置に動かすこと で，望みの動作経路を指定する，実機を用いた教示で あるため, ロボットの高い繰り返し精度を利用できる メリットがある.これはティーチングペンダントを使 うのに比べると非熟練者にとって分かりやすい教示法 であるが，オペレータ自身が「良い」ロボットの動作 を考えて教えなければならないことには変わりない. たとえばロボットのサイクルタイムを短縮化したいと 考えたとき, 最適な動作を教示するためには各軸の仕 様やロボットの運動学の非線形性を把握しておく必要 があり，非熟練者にとっては簡単とは言えない.

そこで本論文では，非熟練者でも容易に品質の高い 教示を行えるような手法の提案を行う.この手法では, オペレータはマニピュレータの手先を持ってさまざま に動かし，そのボディで空間を掃引させる.この掃引 


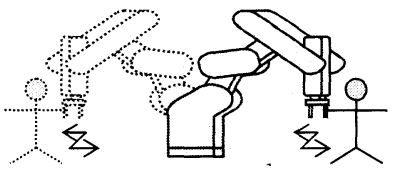

Manual Volume Sweeping

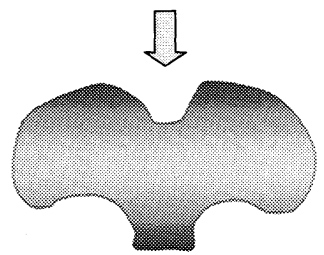

Swept Volume as a Part of Free Space



Motion Planning within Swept Volume

Fig. 1 Overview of Proposed Robot Programming Method

空間の情報を動作計画アルゴリズムで利用することに より，特別な知識・技能が無くてもサイクルタイムの 短いロボットの動作を教示できるようにすることを目 指す。

\section{2. 提案する教示手法の概要}

長谷川らはロボットの遠隔操作システムにおいて, ロボットのボディが掃引した空間の情報に基づいて, 障害物のない自由空間の情報を獲得する, というアイ デアを提案している(7). 本論文では, このアイデアを, 通常の産業用マニピュレータの教示に利用することを 考える.

教示の手順は以下のようになる（図 1）.

1. マニピュレータを, 直接教示の際と同様にダンピ ング制御する．オペレータがマニピュレータの手 先を持って, 障害物にぶつからないようにさまざ まに動かし，マニピュレータのボディで空間を掃 引する (図 2)。この間のマニピュレータの関節角 情報をすべて記録しておく，また，ロボットの動 作開始位置, 終了位置もこのときに教示しておく.

2. 記録された関節角情報を用いて，マニピュレータ のボディが掃引した空間を計算する（図 3）。こ の掃引空間は，マニピュレータが障害物にぶつか らない自由空間（の一部）となる ${ }^{(8)}$.

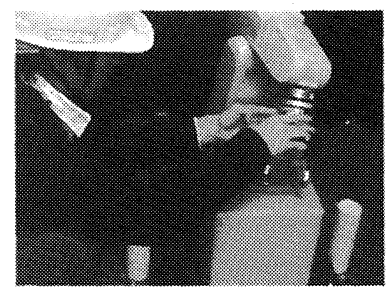

Fig. 2 Manual Volume Sweeping



Fig. 3 Calculation of a Swept Volume

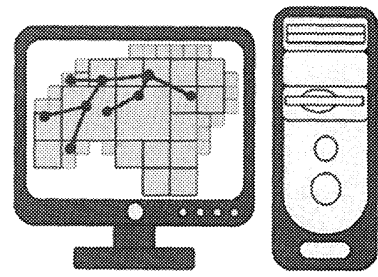

Fig. 4 Motion Planning

3. 動作計画アルゴリズムを用いて，動作開始位置と 終了位置を結ぶ掃引空間内の経路を自動生成する (図 4).

4. 得られた経路に従って, ロボットを動かし，作業 を実行させる（図 5)。

この方法では, オペレータの手で空間掃引をすること で, マニピュレータの自由空間の情報を, 簡便かつ直 感的に獲得することができる，そして，この自由空間 の情報に基づいて動作計画アルゴリズムを用いること で,「良い」ロボットの動作（たとえばサイクルタイ ムの短い動作）を求めることができる，この一連の教 示手順は, 特別な技能を必要としないため, 非熟練者 でも品質の高い教示が実現できるようになると期待さ れる。

\section{3. 空間掃引}

提案する教示手法では, まず, マニピュレータを力 制御（ダンピング制御）し，外力によって自由に動か せるようにする，そして，オペレータが（值接教示の ように) 手でマニピュレータを動かす（図 2)，直接 教示と異なるのは, マニピュレータの望みの動作自体 


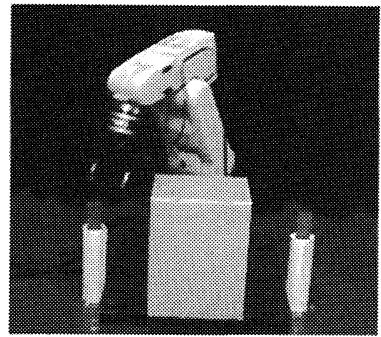

Fig. 5 Execution of Planned Motion
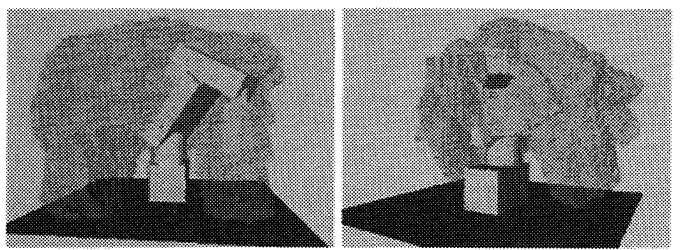

Fig. 6 Swept Volume

はここでは教える必要が無いことである.オペレータ は，障害物にぶつからないようにマニピュレータのボ ディで周りの空間をさまざまに掃引するだけである. この掃引の間の関節角情報はすべて記録しておく.

ここで，コンフィギュレーション空間（関節空間） におけるマニピュレータの動作は一次元の軌跡である のに対し，デカルト空間における掃引空間は三次元の 体積を持つことに注意されたい.この掃引空間はマニ ピュレータの自由空間の一部となる，なぜなら，その ボディが障害物にぶつからずに通過した空間だからで ある.この掃引空間内には, マニピュレータが実際に はとらなかったコンフィギュレーションも含まれるた め, これによって多様なロボット動作の生成が可能と なる.

なお，このステップではマニピュレータの動作開始 位置と終了位置も合わせて指定することにする. マニ ピュレータの繰り返し精度の高さを利用することで, これら重要な点での位置精度を確保する.

\section{4. 掃引空間の計算}

次に, 記録された関節角情報とマニピュレータのボ ディの形状情報から, 掃引空間の計算を行う. 掃引空 間の峳密な表現は難しいので, ここでは octree を用い た近似表現を用いる.

計算に当たっては, まず記録された関節角情報を ソートし, 重複するコンフィギュレーションを除去す る.そして，各サンプリング時間でのマニピュレータ のボディおよびマニピュレータの作業空間のボクセル

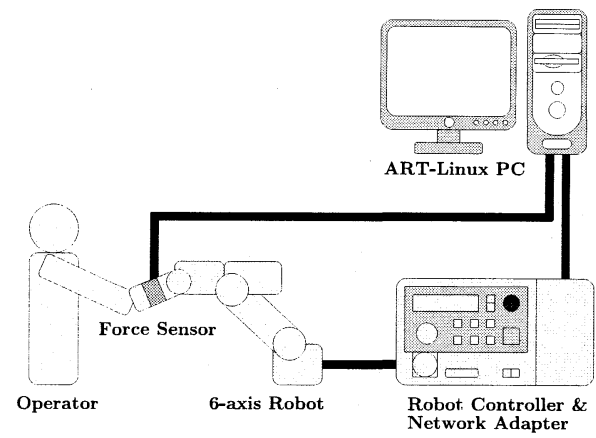

Fig. 7 Experimental Setup

との干渉チェックを行うことで, 掃引空間を表現する octree を生成する. すべての干渉チェックが終わった ときに得られる octree は, マニピュレータの自由空間 （の一部）を表している（図6）.

\section{5. 動作計画と実行}

前のステップで計算された掃引空間の余集合は, 仮 想的な障害物と考えることができる. そこで, 動作計 画アルゴリズムを用いて，この仮想障害物にぶつか らないような, 動作開始点と終了点を結ぶ経路を求め る. この動作計画問題はごく一般的なものであるため, 種々のアルゴリズムが適用できるが，マニピュレータ のサイクルタイムを短縮するような経路が求まること が望ましい。

最後に, 得られた経路に従ってロボットを動かすこ とによって, 教示は完了する.

\section{6. 実 験 環 境}

教示実験を行うために, 図 7 に示す実験環境を用意 した.

6.1 ハードウェア環境 三菱電機製 6 自由度マ ニピュレータ RV-1A を用い, Ethernet 経由で 7.1 [ms] 間隔で PC から指令を送り制御を行う。関節角データ も同じ間隔で PCに送って記録する。また，ニッタ製 の 6 軸力センサ 67M25A-140をマニピュレータの手首 に取り付け，力制御に用いる.

6.2 ソフトゥェア環境 マニピュレータの制御 プログラムは ART-Linux ${ }^{\left({ }^{9}\right)}$ 上で動作させる. 空間掃引 時には，ノイズによる誤動作を避けるため, わずかに 不感帯を設けてマニピュレータをダンピング制御する.

掃引空間の計算のプログラムでは，干渉チェックに FreeSOLID $^{(10)}$ を利用し, マニピュレータは 5 つの直 方体と 2 つの円筒（いずれも剛体）で近似する. 掃 


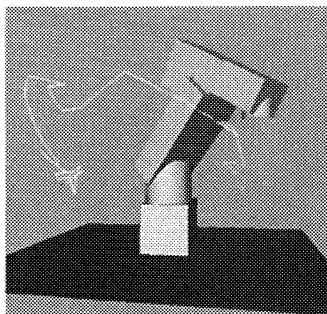

(a) Original Path

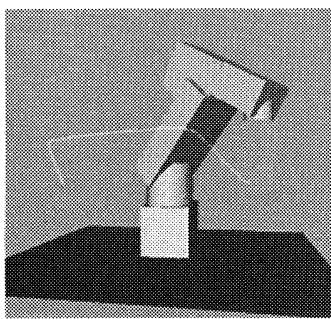

(b) Smoothed Path
Fig. 8 Planned Path by MPK

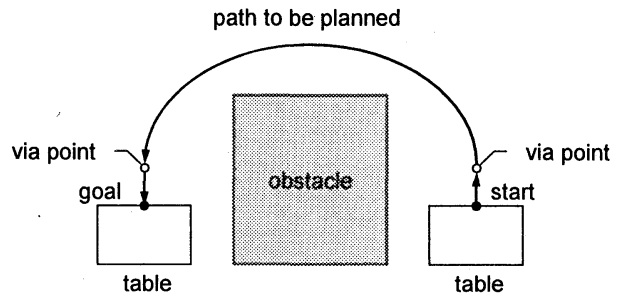

Fig. 9 Target Task

引空間を表現するために, マニピュレータの作業空間 をすっぽり覆うような一辺 $1200[\mathrm{~mm}]$ の立方体を考 え，これを最小のボクセルのサイズが一辺約 9.4 [mm] $\left(=1200 / 2^{7}[\mathrm{~mm}]\right)$ となるように分割して octree 表現 する.

動作計画には Motion Planning Kit (MPK) ${ }^{(11)}$ に 実装されている SBL (a single-query bi-directional probabilistic roadmap planner with lazy collision checking) ${ }^{(12)}$ を用いる. SBL によって得られる経路 はジグザグだが, MPK のスムージング機能によって 改善できる（図 8).この機能では, 経路中にランダム に 2 点を取り, その間を衝突なしに直線で結べるかど うかを調べ，結べる場合はそれを新たな経路とする， という処理を繰り返す．また，関節変数を各関節の最 大速度で正規化して表現することで，各軸の仕様を考 慮した上での「最短」経路が得られるようにする.

なお, 以降の計算結果は Core 2 Duo E6600 CPU $(2.4 \mathrm{GHz})$ を搭載した Linux PC での結果である.

\section{3 対象とする作業ここでは対象作業として，} 簡単なピックアンドプレイス作業を考える.ただし， 問題を単純にするために，グリッパの開閉は考えず, 移動動作だけを扱う。マニピュレータは動作開始位置 から終了位置まで，障害物を回避しながら移動するこ とになる（図 9）.

動作開始位置・終了位置付近での空間掃引の手間を 省くために，ここではこれらの位置の上方に経由点 を設定し，これを空間掃引時に併せて指定することと
した. マニピュレータは動作開始位置からこの経由点 まで（あるいは経由点から動作終了位置まで）は直線 補間で動作し, 経由点の間は動作計画アルゴリズムに よって得られた経路で動作する.

\section{7. 教 示 実 験}

7.1 実験条件 提案手法の評価を行うために, 他 の教示手法との比較実験を行った.

空間掃引を利用したロボット教示 本論文での提 案手法である. SBL で乱数が利用されていることの影 響を抑えるため, 毎回動作計画を三回繰り返し, 最も サイクルタイムの短い経路を採用することとした．マ ニピュレータは, 得られた経路に沿って最高速で動作 させる.なお，今回の実験環境では，空間掃引の進行 状況をオペレータに呈示する機能を実装していない. このため, これ以上空間掃引をやっても無意味である と提案手法の開発者が経験的に判断した時点で, 掃引 の中止を指示することとした.

ティーチングペンダントを使った教示再生 オペ レータはティーチングペンダントを使って経由点を複 数指定する. 続いて MoveMaster 言語のプログラムを 入力し, マニピュレータを経由点に沿って最高速で直 線補間動作させる.

直接教示による教示再生 オペレータは直接教示 によって複数の経由点を指定する. すなわち, 力制御 状態でェンドェフェクタを持って望みの位置に動かす。 続いて MoveMaster 言語のプログラムを入力し，マニ ピュレータを経由点に沿って最高速で直線補間動作さ せる.

以上の $3 つ$ 方法について，産業用マニピュレータ の教示経験の無い 5 人の被験者で教示実験を行った.

7.2 実験結果表 1 に, 提案手法における掃引 空間の計算結果を示す. また，教示にかかった時間の 総計を図 10 に示す.一見，直接教示が最も良く，ま た本論文の提案手法が最も悪いように思われる. しか し，オペレータの作業時間で比べると，提案手法は他 の手法と大差ないことが分かる（図 11）。これは，提 案手法においては，時間がかかっているのは自動処理 の部分（掃引空間の計算および動作計画）であるため である（図 12）。

教示された動作のサイクルタイムを比較すると，提案 手法は他の手法に比べて，オペレータ E の場合（MPK の動作計画が失敗したため結果を載せていない）を除 けば，22〜44\%のサイクルタイム短縮が実現されてい る（図 13）。したがって，本論文の提案手法は，多く の場合において，オペレータの作業時間をそれほど増 
Table 1 Calculated Swept Volumes

\begin{tabular}{c|ccccc}
\hline Operator & A & B & C & D & E \\
\hline \hline \# of recorded configurations & 52714 & 60654 & 73806 & 48489 & 85097 \\
\# of unique configurations & 49804 & 55893 & 68400 & 42959 & 82739 \\
\# of nodes in octree & 24477 & 25652 & 26748 & 23644 & 22304 \\
swept volume $\left[\mathrm{m}^{3}\right]$ & 0.174 & 0.184 & 0.191 & 0.171 & 0.152 \\
\hline
\end{tabular}

やさずに，短いサイクルタイムの動作を教示できると 考えられる.

$7 \cdot 3$ 考察 以上の結果から, 提案手法は, 非熟 練者にとっても容易な教示手法でありながら,「良い」 ロボットの動作を生成可能であることが分かる.

提案手法の一つの問題は, 動作計画の失敗の問題で ある.オペレータEの場合では, MPKが経路を見つけ ることに失敗してしまった。これは掃引が不十分だっ たために狭险部ができてしまったことが理由であると 考えられる.このような場合への対策として, 空間掃 引時の最初に, オペレータが必ず動作開始位置から終 了位置まで一回動かすようにすることが考えられる. そうしておけば, 動作計画が失敗してしまった場合は, このときの経路（もしくはこれをスムージングした経 路）を次善の策として用いることができる．また，別 の対策法として, 追加の空間掃引を行って狭险部の解 消を図ることも可能である.

もう一つの問題は, 計算に要する時間である. 計算 中はオペレータは拘束されないので他の作業を行うこ とが可能ではあるが, 教示にかかる総時間はやはり短 いほうが望ましい. 図 12 に示すように, 計算時間の 大半は掃引空間の計算に費やされている. 空間掃引時 に記録されたコンフィギュレーションの数を $n$, octree の最大分割レベルを $d$ (すなわち, 一辺を $1 / 2^{d}$ まで分 割する）とすると, 計算量は最悪で $O\left(8^{d} n\right)$ となる. し たがって, 掃引空間の正確な表現を求めるのであれば, よりいっそうの計算量の削減が必要となる. Octreeを 構成する部分木は完全に並列に計算できるので, コン ピュータの台数を増やせば, 安直に計算量を減らすこ とができる.

教示実験において, 何人かのオペレータは, 提案手 法に対する感想として, 十分な空間掃引ができたか否 かの判断が難しいと述べている.リアルタイムに掃引 空間を計算し表示することが，一つの対策になると考 えられる.

さらに, 空間掃引に要する時間の削減のために, マ ニピュレータの手先に掃引用アタッチメントを装着す ることも考えられる（図 14）。適切な形状・大きさの

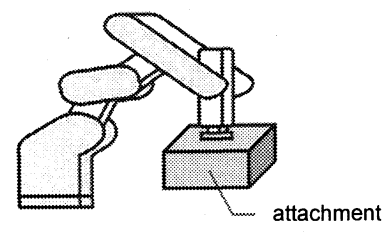

Fig. 14 Attachment for Efficient Volume Sweeping

アタッチメントを利用することで, 空間掃引の効率化 と安全化が図れると思われる.

\section{8. 結 論}

本論文では, 産業用マニピュレータのための教示手 法の提案を行った.この手法は, マニピュレータのボ ディの掃引空間が, 障害物にぶつからない自由空間を 表すという長谷川らのアイデア ${ }^{(7)}$ に基づいている.

提案手法においては, オペレータがさまざまにマニ ピュレータを動かしてそのボディで空間を掃引するこ とによって, 特別な技能や経験を要することなく, サ イクルタイムの短いロボットの動作を教示することが 可能になる. 教示実験においても, 提案手法は他の一 般的な手法と比較して，オペレータの作業時間はあま り変わらないが, 良い動作の教示を行えることが示さ れた.

今後の課題としては, 種々のロボット作業に対する 提案手法の有効性の検証, および 7.3 節で述べた問題 点の解決が挙げられる.

\section{文献}

(1) Matsushima, K., Offline Teaching, Journal of the Robotics Society of Japan, Vol. 13, No. 5 (1995), pp. 611-614.

(2) Hwang, Y. K., and Ahuja, N., Gross Motion Planning - a Survey, ACM Computing Surveys, Vol. 24, No. 3 (1992), pp. 219-291.

(3) Shiller, Z., Optimal Robot Motion Planning and WorkCell Layout Design, Robotica, Vol. 15, No. 1 (1997), pp. 31- 40 .

(4) Latombe, J.-C., Motion Planning: A Journey of Robots, Molecules, Digital Actors, and Other Artifacts, International Journal of Robotics Research, Vol. 18, No. 11 (1999), pp. 1119-1128. 


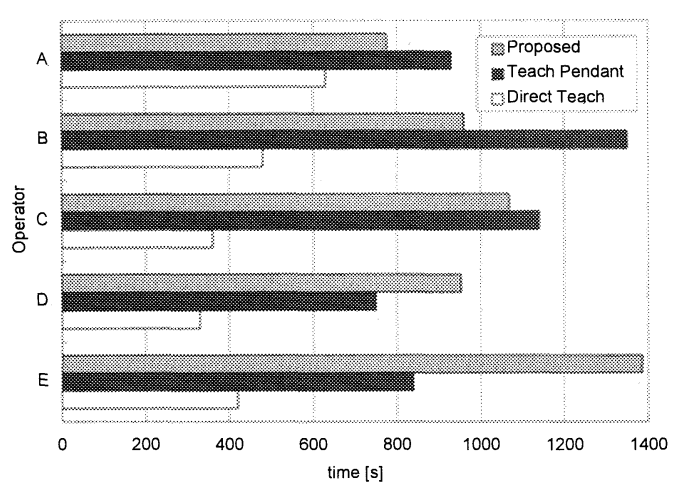

Fig. 10 Total Time for Robot Programming

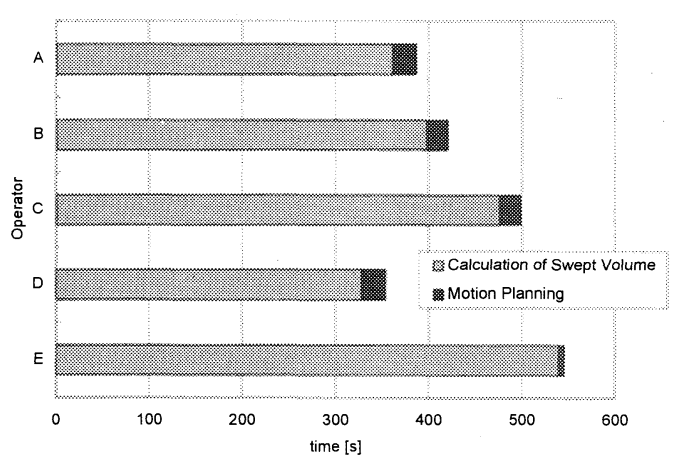

Fig. 12 Time for Computation in Our Proposed Method

(5) Ando, S., A Fast Collision-Free Path Planning Method for a General Robot Manipulator, Proceedings of 2003 IEEE International Conference on Robotics and Automation (2003), pp. 2871-2877.

(6) Sugimoto, K., Industrial Applications of Force Feedback Control, Journal of the Robotics Society of Japan, Vol. 9 , No. 6 (1991), pp. 794-798.

(7) Hasegawa, T. et al., Collision-Free Path Planning of a Telerobotic Manipulator based on Swept Volume of Teleoperated Manipulator, Journal of the Robotics Society of Japan, Vol. 22, No. 4 (2004), pp. 515-518.

(8) Abdel-Malek, K. et al., Swept Volumes: Foundation, Perspectives, and Applications, International Journal of

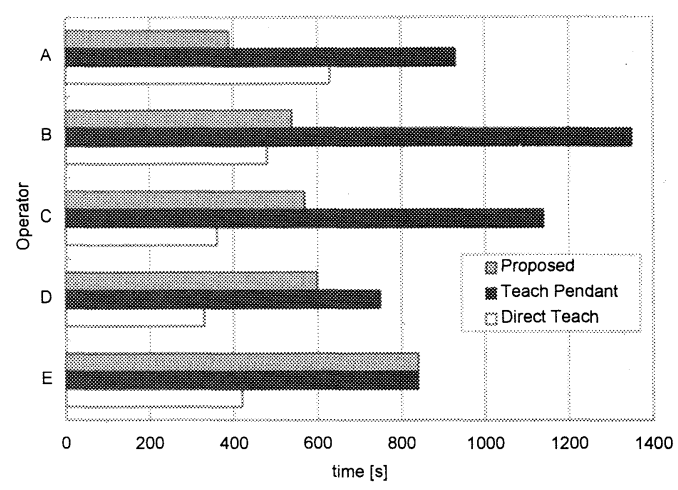

Fig. 11 Time for Manual Operations

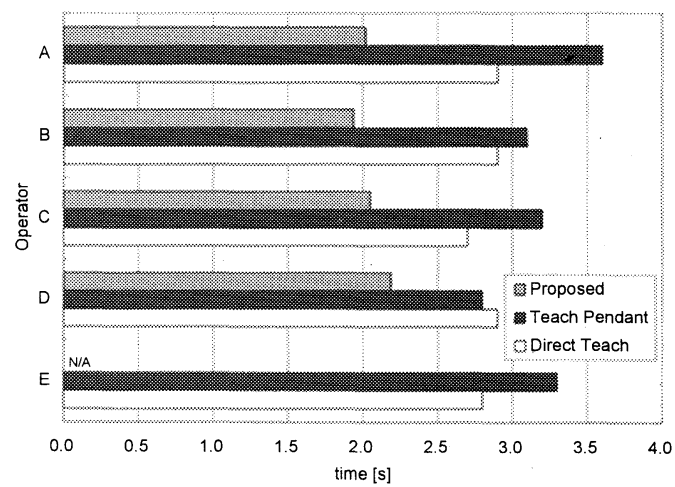

Fig. 13 Cycle Time of Programmed Motions

Shape Modeling, Vol. 12, No. 1 (2006), pp. 87-127.

(9) Ishiwata, Y., ART-Linux, http://art-linux. sourceforge.net/.

(10) van den Bergen, G., FreeSOLID, http: //sourceforge.net/projects/freesolid/.

(11) Schwarzer, F. et al., Motion Planning Kit, http://ai. stanford. edu/ mitul/mpk/.

(12) Sánchez, G. and Latombe, J.-C., A Single-Query BiDirectional Probabilistic Roadmap Planner with Lazy Collision Checking, Springer Tracts in Advanced Robotics, Vol. 6 (2003), pp. 403-418. 